\title{
In vitro culture on Matrigel favors the long-term maintenance of rat zona glomerulosa-cell differentiated phenotype
}

\author{
RAFFAELLA SPINAZZI, LUCIA PETRELLI, DIEGO GUIDOLIN, GIANNI CARRARO, \\ VALENTINA CASALE, CINZIA TORTORELLA, GIULIANO NERI, GIOVANNA ALBERTIN, \\ PAOLA G. ANDREIS and GASTONE G. NUSSDORFER
}

Department of Human Anatomy and Physiology, Section of Anatomy, University of Padua, I-35121 Padua, Italy

Received December 16, 2005; Accepted January 27, 2006

\begin{abstract}
Zona glomerulosa (ZG) cells cultured on plastic within few days dedifferentiate losing their capacity to secrete aldosterone (ALDO) in appreciable amounts. Evidence indicates that extracellular matrix modulates the secretory behavior of adrenocortical cells cultured in vitro. Hence, we compared the morphology and function of rat ZG cells grown on plastic and Matrigel basement membrane matrix (hereinafter Matrigel) for up to 12 days. At day 3, no significant differences were observed between cells cultured on plastic and Matrigel. Starting from day 6, ZG cells cultured on plastic lost their ultrastructural differentiated features (mitochondria with tubular cristae, smooth endoplasmic reticulum cisternae and lipid droplets), exhibiting a fibroblast-like appearance. The mRNA expression of the main steroidogenic enzymes, as evaluated by real-time polymerase chain reaction, the baseline secretion of ALDO and other post-pregnenolone hormones, as evaluated by high pressure liquid chromatography, and the secretory response to ACTH, angiotensin-II and $\mathrm{K}^{+}$, as evaluated by radioimmunoassay, displayed a timedependent decrease. Matrigel was found to maintain unchanged both the ultrastructure and the expresion of steroidogenic enzymes of ZG cells until day 12 of culture. Baseline and agonist-stimulated steroid-hormone secretion decreased with the duration of culture on Matrigel, but was always higher than that of ZG cells grown on plastic. Hence, our study clearly indicates that the culture on Matrigel favors the maintenance of rat ZG-cell differentiated phenotype, allowing the conclusion that this technique is suitable for long-term in vitro investigations.
\end{abstract}

\section{Introduction}

Primary culture of adrenocortical cells is a widely used experimental model for the study of steroid-hormone secretion

Correspondence to: Professor Gastone G. Nussdorfer, Department of Human Anatomy and Physiology, Section of Anatomy, Via Gabelli 65, I-35121 Padua, Italy

E-mail: gastone.nusdorfer@unipd.it

Key words: zona glomerulosa cells, in vitro culture, extracellular matrix, Matrigel, steroidogenic-enzyme expression, steroid secretion and its regulation. However, the limited life-span of adrenocortical cells in culture, due to their rapid dedifferentiation into fibroblast-like cells (reviewed in ref. 1), prevents the use of primary cultures in long-term studies. This is particularly true in the case of zona glomerulosa (ZG) cells, which within 48-72 h of in vitro growth lose their capability to secrete aldosterone (ALDO).

The use of stabilized and immortalized adrenocortical cell lines could overcome these difficulties (reviewed in ref. 2). Unfortunately, the presently available cell lines, that are derived from adrenocortical tumors, do not appear to be a very suitable model for investigating adrenal gland physio$\operatorname{logy}$, inasmuch as their ultrastructural features do not reflect those of normal adrenocortical cells $(1,3,4)$ and their steroidogenic capacity is abnormal (murine Y1 cells do not secrete corticosterone) (2), almost completely absent (human SW-13 cells) (3) or very low (human H295 cells produce only small amounts of ALDO) $(2,4)$. A recently described cell line obtained from mice harboring a temperature sensitive large T-antigen gene of simian virus 40 does not express ALDO synthase (5). Moreover, despite the fact that the rat is the most common species used in adrenocortical studies, rat adrenocortical cell lines are not yet available. Hence, the need of a primary culture technique allowing the long-term preservation of the differentiated phenotype of rat adrenocortical, and especially ZG, cells is compelling.

Numerous lines of evidence indicate that extracellular matrix plays an important role in modulating specific cell functions (reviewed in ref. 6), including the secretory behavior of human adrenocortical cells cultured in vitro (7). Matrigel basement membrane matrix (hereinafter Matrigel) is a solubilized basement membrane preparation extracted from the Engelbreth-Holm-Swarm mouse sarcoma (8), which was found to be effective for the attachment and differentiation of several types of cells, including hepatocytes, and Sertoli, thyroid and endothelial cells (9-12). Based on these findings, we thought worthwhile to investigate the effects of the culture on Matrigel, as compared to the conventional growth on plastic, on the morphology and function of rat ZG cells.

\section{Materials and methods}

Animals and reagents. Adult male Sprague-Dawley rats were purchased from Charles-River (Como, Italy), and the protocol of the experiments was approved by the local Ethics Committee 


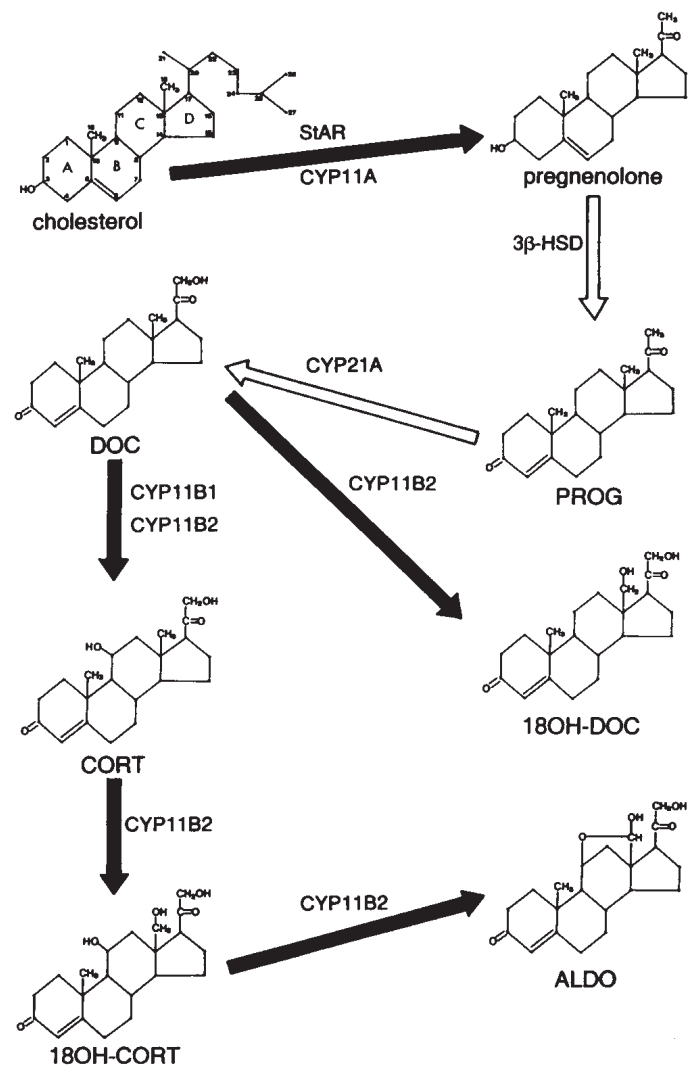

Figure 1. Pathway of ALDO synthesis in rat ZG cells. Steps occurring in mitochondria and SER are indicated by solid and void arrows, respectively. for Animal Studies. Growth factor reduced Matrigel was obtained from BD Biosciences (Bedford, MA), and iTaq DNA polymerase from Bio-Rad Laboratories (Milan, Italy). Collagenase and deoxyribonuclease were provided by Worthington Biochemical Corp. (Lake Wood, NJ), tritiated aldosterone and corticosterone by Amersham (Aylesbury, UK), and ACTH and angiotensin-II (Ang-II) by Phoenix Pharmaceuticals (Belmont, CA). Glutaraldehyde and osmium tetroxide were purchased from Serva (Heidelberg, Germany), and Epon-812 resin from Electron Microscopy Sciences (Fort Washington, PA). Dulbecco's modified Eagle's medium (DMEM), fetal calf serum (FCS), anti-aldosterone and anticorticosterone antisera, antibiotics, and all other chemicals were obtained from Sigma-Aldrich Corp. (St. Louis, MO).

Tissue culture. Rats were sacrificed by cervical dislocation, and adrenal glands were promptly removed and decapsulated to separate ZG. Dispersed ZG cells were obtained by sequential enzymatic digestion (collagenase- $\mathrm{I}, 2 \mathrm{mg} / \mathrm{ml}$ and deoxyribonuclease-I, $0.1 \mathrm{mg} / \mathrm{ml}$ in DMEM) and mechanical disaggregation. The purity of ZG-cell preparations, as checked by phase microscopy, was higher than $92 \%$. Dispersed cells were seeded at a density of $2 \times 10^{4}$ cells $/ \mathrm{cm}^{2}$ into 24-well plates, polystyrene dishes either uncoated or precoated with Matrigel $(1 \mathrm{mg} / \mathrm{ml})$. Cells were cultured at $37^{\circ} \mathrm{C}$ in DMEM (supplemented with $20 \% \mathrm{FCS}, 100 \mathrm{U} / \mathrm{ml}$ penicillin, $100 \mu \mathrm{g} / \mathrm{ml}$ streptomycin and $100 \mathrm{U} / \mathrm{ml}$ amphotericin) in an atmosphere of $95 \%$ air- $5 \% \mathrm{CO}_{2}$ (13). Medium

Table I. Real-time PCR primers and PCR products.

\begin{tabular}{|c|c|c|c|c|}
\hline Primer & Sequence & $\begin{array}{l}\text { Annealing } \\
\text { temp. }\left({ }^{\circ} \mathrm{C}\right)\end{array}$ & $\begin{array}{l}\text { Product } \\
\text { size (bp) }\end{array}$ & $\begin{array}{l}\text { Accession } \\
\text { number }\end{array}$ \\
\hline \multicolumn{5}{|l|}{ StAR } \\
\hline Sense & 5'-GCATACTCAACAACCAGGAAGGCT-3' & & & \\
\hline Antisense & 5'-TGCGGTCCACCAGTTCTTCATAGA-3' & 60 & 159 & NM_031558 \\
\hline \multicolumn{5}{|l|}{ CYP11A } \\
\hline Sense & 5'-AACTAAGACCTGGAAGGACCATGC-3' & & & \\
\hline Antisense & 5'-GGTACTTGCTGAAGTCTCGCTTCT-3' & 60 & 116 & NM_017286 \\
\hline \multicolumn{5}{|l|}{ 3ß-HSD } \\
\hline Sense & 5'-CCACACGGCTTCTGTCATGGAT-3' & & & \\
\hline Antisense & 5'-GCAGTAGATGAAGGCTGGCACA-3' & 60 & 130 & NM_017265 \\
\hline \multicolumn{5}{|l|}{ CYP21A } \\
\hline Sense & 5'-CAAGCAGGACAGCACTTTGC-3' & & & \\
\hline Antisense & 5'-GGGGAAGAACCTGAGAAAGG-3' & 60 & 118 & NM_057101 \\
\hline \multicolumn{5}{|l|}{ CYP11B1 } \\
\hline Sense & 5'-TGCTGGAGAATGTTCATGGAAG-3' & & & \\
\hline Antisense & 5'-ACTCTGTGCTACCATCTCGG-3' & 56 & 168 & RNCP450B \\
\hline \multicolumn{5}{|l|}{ CYP11B2 } \\
\hline Sense & 5'-AGGTGCGTCAGAATGCTCG-3' & & & \\
\hline Antisense & 5'-TAGTGCTGCCACAATGCCAC-3' & 66 & 356 & NM_012538 \\
\hline \multicolumn{5}{|l|}{ GAPDH } \\
\hline Sense & 5'-GGGCTGCCTTCTCTTGTGAC-3' & & & \\
\hline Antisense & 5'-CGCCAGTAGACTCCACGACA-3' & 60 & 243 & NM_017008 \\
\hline
\end{tabular}


was collected at the 3rd, 6th, 10th and 12th day of culture (time 0), as well as $180 \mathrm{~min}$ before and $180 \mathrm{~min}$ after time 0 , and new fresh medium was added. During the second 180min incubation, the medium of some cultures contained $10^{-8} \mathrm{M}$ ACTH, $10^{-8} \mathrm{M}$ Ang-II or $10^{-2} \mathrm{M} \mathrm{K}^{+}$. Collected media were stored at $-80^{\circ} \mathrm{C}$ until hormone assay.

Electron microscopy. Freshly dispersed ZG cells and control cultures were fixed in $3 \%$ phosphate-buffered glutaraldehyde, post-fixed in $1 \%$ osmium tetroxide, dehydrated in a graded ethanol series, and embedded in Epon-812 (3). Thin (60-80 nm) sections were cut with an LKB SuperNova ultramicrotome (Reichert-Jung, Vienna, Austria), counterstained with leadhydroxide, and observed in a Hitachi H-300 transmission electron microscope.

Reverse transcription $(R T)$ real-time polymerase chain reaction $(P C R)$. Freshly dispersed and control ZG cells cultured for 3, 6 and 10 days were harvested and frozen. Total RNA was extracted, and reverse transcribed to cDNA (14-16). The RTreaction solution ( $1 \mu \mathrm{l}$ diluted to $12 \mathrm{ng} / \mathrm{ml}$ ) was added to a mixture (final volume, $25 \mu \mathrm{l}$ ), containing $50 \mathrm{mM} \mathrm{KCl}, 20 \mathrm{mM}$ Tris- $\mathrm{HCl}$ (pH 8.4), 3 mM MgCl $2,0.8 \mathrm{mM}$ dNTPs, and $25 \mathrm{U} /$ $\mu 1$ iTaq DNA polymerase $(17,18)$. PCR was performed in a Bio-Rad I-Cycler iQ Detection System, using the following protocol: denaturation program $\left(95^{\circ} \mathrm{C}\right.$ for $\left.3 \mathrm{~min}\right), 35$ cycles of two steps of amplification $\left(95^{\circ} \mathrm{C}\right.$ for $15 \mathrm{sec}$ and annealing for $30 \mathrm{sec})$, and melting curve $\left(60-90^{\circ} \mathrm{C}\right.$ with a heating rate of $\left.0.5^{\circ} \mathrm{C} / 10 \mathrm{sec}\right)$. The mRNA expression of the following steroidogenic enzymes was assayed: steroidogenic acute regulatory protein (StAR), cytochrome $\mathrm{P}_{450}(\mathrm{CYP})$ side-chain cleavage enzyme (CYP11A), 3ß-hydroxysteroid dehydrogenase (3ß-HSD), c21-hydroxylase (CYP21A), c11-hydroxylase (CYP11B1) and ALDO synthase (CYP11B2) (Fig. 1). Primer sequences, annealing temperature and accession numbers are shown in Table I. During the exponential phase, the fluorescence signal threshold was calculated, and the fraction number of PCR cycles required to reach the threshold (cycle threshold, Ct) was determined. Ct value decreased linearly with increasing input target quantity, and were used to calculate the relative mRNA expression, according to a mathematical quantification model (19). The specificity of amplification was tested at the end of each run by real-time PCR melting analysis, using the I-Cycler iQ software 3.0. All samples were amplified in duplicate and compared with the respective control. Glyceraldehyde-3-phosphate dehydrogenase (GAPDH) was used as reference to normalize data.

Steroid-hormone assay. The concentration of the following post-pregnenolone steroid hormones in the incubation media was assayed by quantitative high pressure liquid chromatography (HPLC) (20): progesterone (PROG), 11-deoxycorticosterone (DOC), 18-hydroxy-11-deoxycorticosterone (18OHDOC), corticosterone (CORT), 18-hydroxy-corticosterone (18OH-CORT) and ALDO (Fig. 1). Steroids were detected by UV absorbance at $240 \mathrm{~nm}$ wavelength and identified by comparison of their retention times with those of the standards. A good separation between the steroid hormones assayed was obtained (Fig. 2), and the final recovery of steroids was $80-85 \%$. Quantification of steroid hormones was based
A

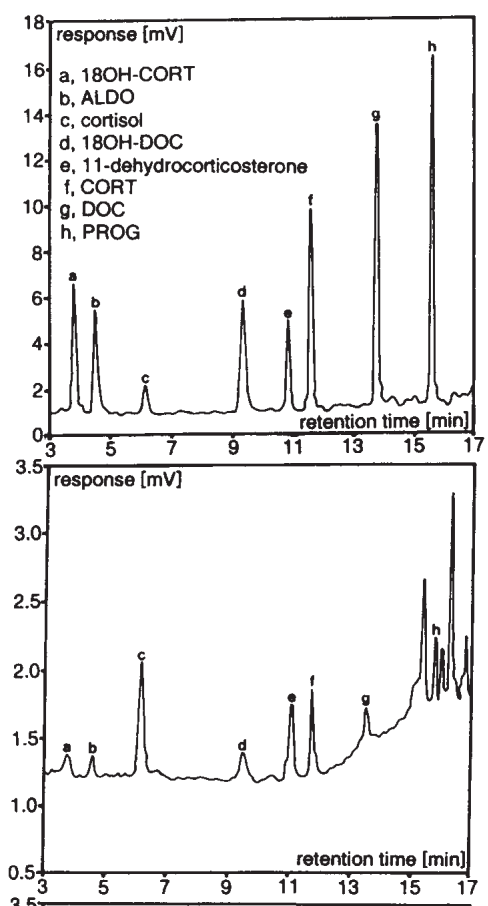

C

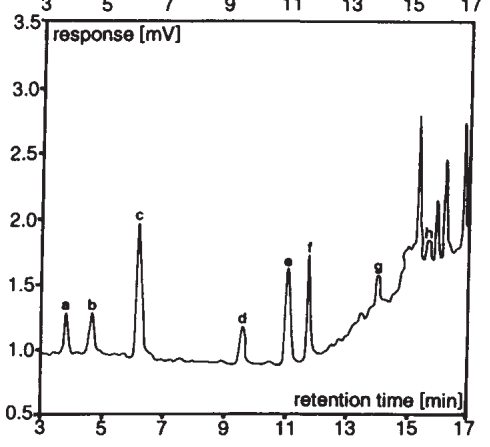

Figure 2. HPLC separation of steroid-hormone standards (A), and exemplary chromatograms of steroid hormones released by ZG cells cultured for 3 days on plastic (B) and Matrigel (C). Cortisol is the internal standard.

on peak area measurement; the sensitivity of our assay system was $1 \mathrm{pmol} / \mathrm{ml}$, and the response of the detector was satisfactorily linear over the range of 1-1000 pmoles and directly proportional to the mass of steroid hormone injected. Intra- and interassay CVs were 5.6 and $7.7 \%$, respectively. CORT and ALDO concentrations were also measured by radioimmuno assay (RIA), as previously detailed (21), using $\left[1,2,6,7-{ }^{3} \mathrm{H}\right]-\mathrm{ALDO}$ and $\left[1 \alpha, 2 \alpha(\mathrm{n})-{ }^{3} \mathrm{H}\right]$-CORT (SA, 1.96 $\mathrm{TBq} / \mathrm{nmol}$ ) and antisera developed in rabbit. ALDO RIA: sensitivity, $5 \mathrm{pg} / \mathrm{ml}$. Cross-reactivity: ALDO, 100\%; and 17iso-ALDO and other steroids, $<0.1 \%$. Intra- and interassay CVs, 5.3 and $7.1 \%$, respectively. CORT RIA: sensitivity, 50 $\mathrm{pg} / \mathrm{ml}$. Crossreactivity: CORT and cortisol, 100\%; DOC and PROG, 2\%; and other steroids, $<0.001 \%$. Intra- and interassay CVs, 7.5 and $8.8 \%$, respectively.

Statistics. Data were expressed as means \pm SEM of four separate experiments. The statistical comparison was done by ANOVA, followed by Duncan's multiple range test.

\section{Results}

Morphology. Phase microscopy showed that ZG cells grown for 3 days on either plastic or Matrigel displayed a polygonal 

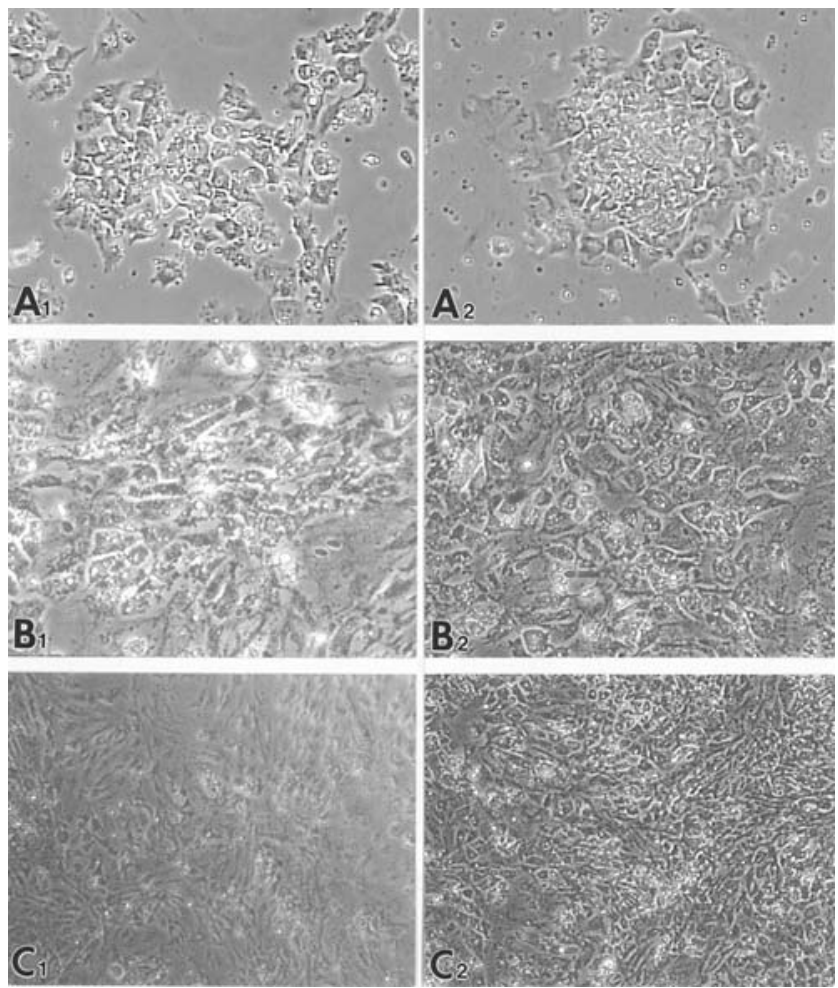

Figure 3. Phase-contrast micrographs of rat ZG cells cultured for 3 (A), 6 (B) and 12 days $(\mathrm{C})$ on plastic (A1, B1 and $\mathrm{C} 1)$ or Matrigel (A2, B2 and $\mathrm{C} 2)$. At day 3 of culture on both plastic and Matrigel (A1 and A2), ZG cells display a polygonal shape and contain abundant clear vacuoles (lipid droplets). By prolonging the culture on plastic, ZG cells progressively assume an elongated fibroblast-like appearance (B1 and $\mathrm{C} 1)$, while when grown on Matrigel ZG cells keep the epithelial-like morphology (B2 and C2). Magnification x55.

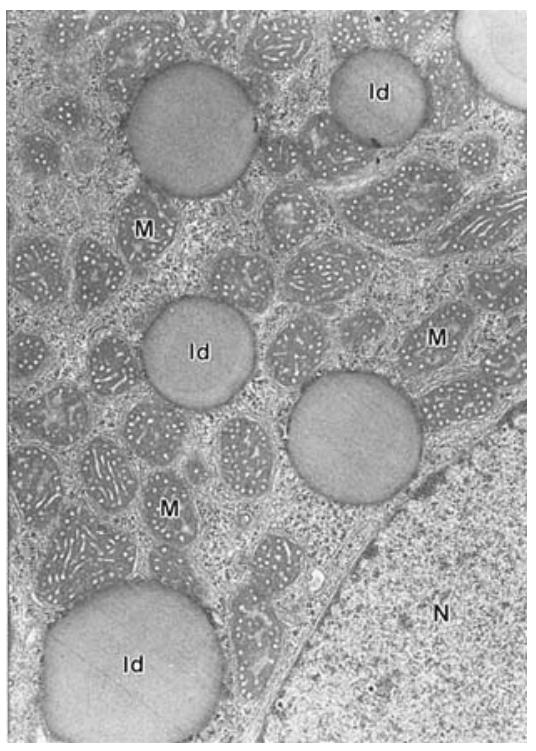

Figure 4. Electron micrograph of a freshly dispersed rat ZG cell. Mitocondria (M) contain tubular cristae, lipid droplets (ld) are numerous, and SER and RER cisternae, as well as free ribosomes, are present in the cytoplasm. N, nucleus. Magnification x9600.

shape and contained several lipid droplets (Fig. 3A). After 6,10 or 12 days of culture on plastic, ZG cells exhibited a fibroblast-like elongated shape and were deprived of lipid
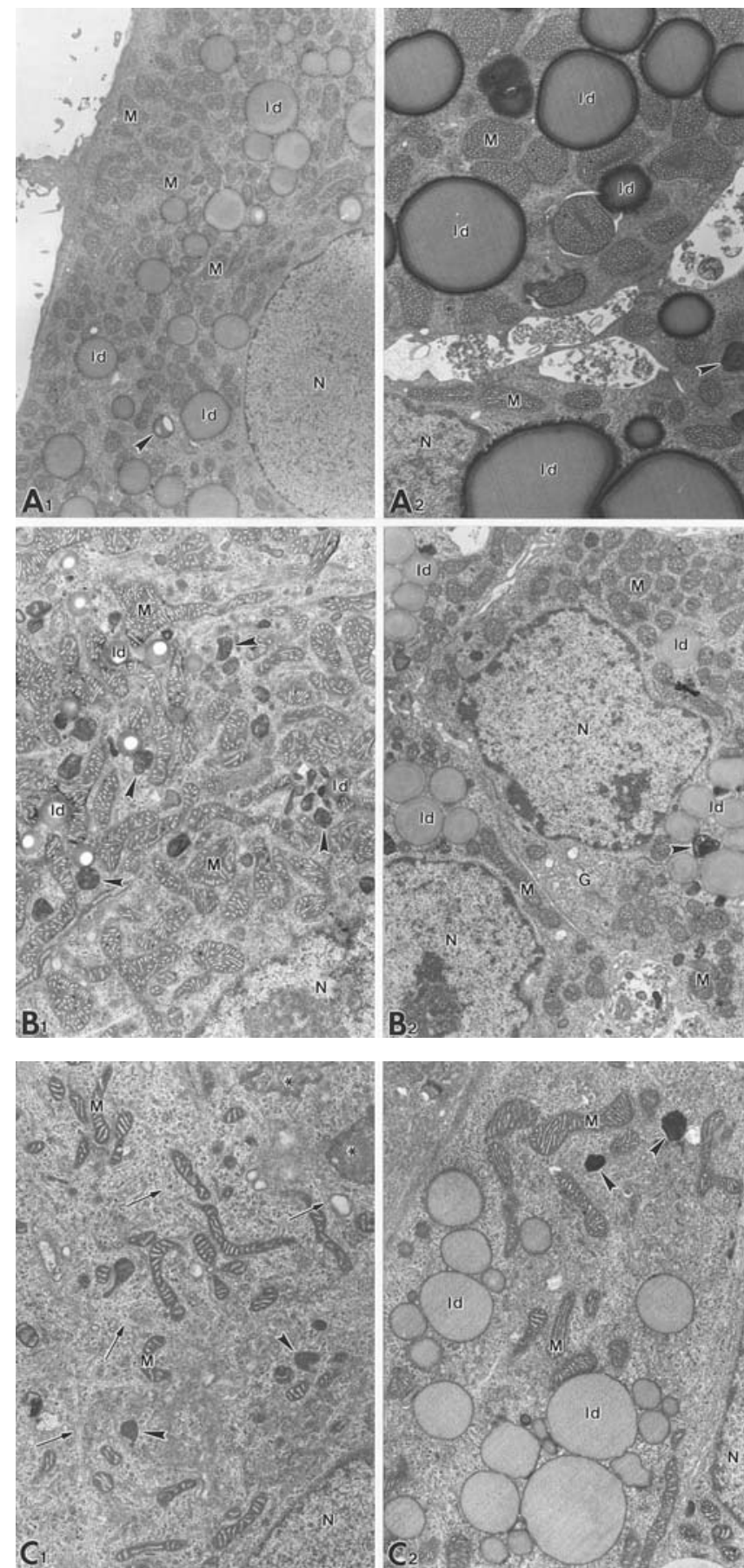

Figure 5. Low power electron micrographs illustrating the ultrastructural features of rat ZG cells cultured for 3 (A), 6 (B) and 12 days (C) on plastic (A1, B1 and C1) or Matrigel (A2, B2 and C2). After a 3 day culture on both plastic and Matrigel (A1 and A2), ZG cells retain the morphology of freshly dispersed cells: mitochondria (M) display tubular cristae and lipid droplets are abundant. After a 6 day culture on plastic (B1), ZG cells show irregularly-shaped elongated mitochondria (M) endowed with laminar cristae, few small lipid droplets (ld) and numerous dense bodies (arrow heads) of probable lysosomal nature. Conversely, ZG cells grown on Matrigel (B2) are still provided with mitochondria (M) with tubular cristae, several lipid droplets (ld) and a well-developed juxta-nuclear Golgi apparatus (G). After a 12 day culture on plastic (C1), ZG cells lose their differentiated morphological phenotype: mitochondria (M) are slender with few lamellar cristae, lipid droplets are absent, and dense bodies (arrowheads) are abundant; secondary lysosomes (asterisks) and several microtubules (arrows) can be observed. In contrast, when grown on Matrigel for 12 days (C2), ZG cells, although displaying poorly differentiated mitochondria (M), still possess abundant lipid droplets (ld) and SER and RER profiles. N, nucleus. Magnification: (A1), x3350; (A2), x5900; (B1), x5900; (B2), x4350; (C1), $\mathrm{x} 5900 ;(\mathrm{C} 2), \mathrm{x} 5600$. 


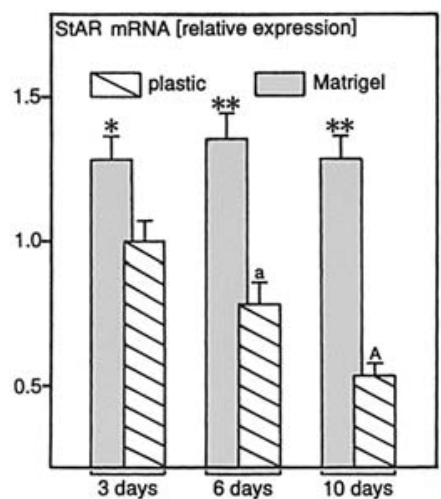

Figure 6. StAR mRNA expression in rat ZG cells cultured on plastic or Matrigel. Data are expressed as percent change from StAR expression in cells grown for 3 days on plastic (taken equal to 1). Bars are means \pm SEM $(\mathrm{n}=4) .{ }^{*} \mathrm{P}<0.05$ and ${ }^{* *} \mathrm{P}<0.01$ from the respective plastic value; ${ }^{\mathrm{P}}<0.05$ and ${ }^{\mathrm{A}} \mathrm{P}<0.01$ from the respective 3 -day value.

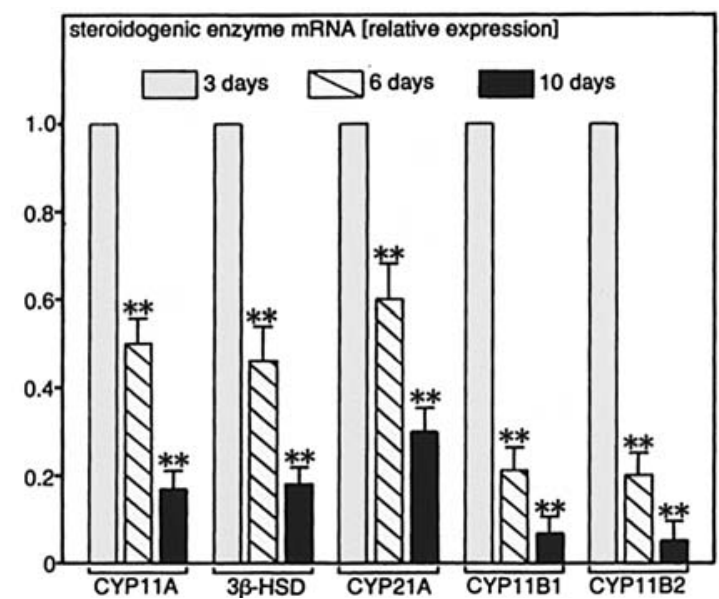

Figure 7. Steroidogenic-enzyme mRNA expression in rat ZG cells cultured on plastic. Data are expressed as percent change from the expression in cells grown for 3 days (taken equal to 1$)$. Bars are means $\pm \operatorname{SEM}(n=4) .{ }^{* *} \mathrm{P}<0.01$ from the respective 3 -day value.

droplets (Fig. 3B1 and C1). In contrast, when cultured on Matrigel, ZG cells retained their epithelial-like morphology (Fig. 3B2 and C2). Electron microscopy demonstrated that after a 3 day culture on plastic ZG cells possessed the morphology of freshly-dispersed cells: mitochondria with tubular cristae, smooth endoplasmic reticulum (SER) profiles, lack of rough endoplasmic reticulum (RER) cisternae, and abundant lipid droplets (Figs. 4 and 5A1), whereas after 6 days they showed elongated mitochondria with laminar cristae, few small lipid droplets, no SER profiles and several dense bodies of probable lysosomal nature (Fig. 5B1). After 10 and 12 days of growth on plastic, ZG cells exhibited a dedifferentiated appearance: mitochondria were slender and provided with few laminar cristae and lipid droplets were absent (Fig. 5C1). In contrast, when cultured on Matrigel, ZG cells kept the ultrastructural features of freshly dispersed cells until the 6th day (Fig. 5A2 and B2). At days 10 and 12, mitochondria were elongated with prevalent laminar cristae, but lipid droplets were still abundant (Fig. 5C2).

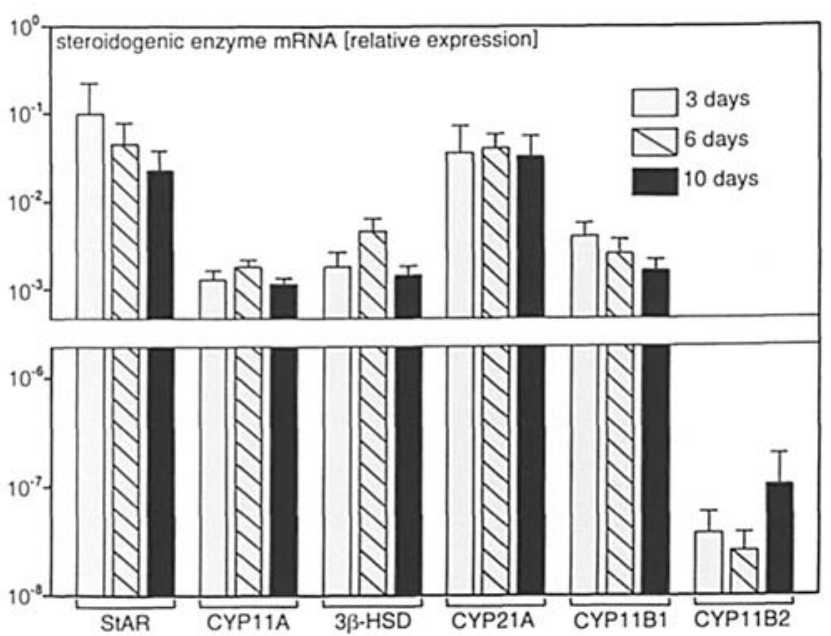

Figure 8. StAR and steroidogenic-enzyme mRNA expression in rat ZG cells cultured on Matrigel. Data are expressed as percent change from the expression in freshly-dispersed ZG cells (taken equal to 1). Bars are means \pm SEM $(n=4)$.

Table II. Baseline post-pregnenolone hormone production from dispersed and 3-day cultured rat ZG cells (means \pm SEM; $n=4$ ).

\begin{tabular}{lccc}
\hline $\begin{array}{l}\text { Hormone } \\
\left(\mathrm{pmol} / 10^{5} \mathrm{cells} \cdot \mathrm{h}\right)\end{array}$ & $\begin{array}{c}\text { Freshly } \\
\text { dispersed } \\
\text { cells }\end{array}$ & $\begin{array}{c}\text { Cells } \\
\text { cultured } \\
\text { on plastic }\end{array}$ & $\begin{array}{c}\text { Cells } \\
\text { cultured on } \\
\text { Matrigel }\end{array}$ \\
\hline PROG & $125.6 \pm 20.8$ & $55.2 \pm 9.3$ & $48.3 \pm 9.0$ \\
DOC & $139.8 \pm 18.1$ & $72.2 \pm 13.4$ & $65.4 \pm 11.9$ \\
18OH-DOC & $98.7 \pm 16.5$ & $41.3 \pm 8.1$ & $38.2 \pm 6.4$ \\
CORT & $518.5 \pm 86.3$ & $270.4 \pm 40.1$ & $291.5 \pm 42.6$ \\
18OH-CORT & $386.2 \pm 59.7$ & $151.3 \pm 26.2$ & $188.2 \pm 30.3$ \\
ALDO & $55.7 \pm 8.5$ & $20.2 \pm 3.9$ & $18.9 \pm 4.1$ \\
\hline
\end{tabular}

Steroidogenic-enzyme expression. Real-time PCR evidenced that mRNA expression of StAR and other main steroidogenic enzymes underwent a progressive decrease with the duration of ZG-cell culture on plastic (Figs. 6 and 7). Or the contrary, the culture on Matrigel preserved the expression of all steroidogenic enzymes until day 10 (Figs. 6 and 8). However, it must be noted that the expression of StAR, CYP11A, 3ßHSD, CYP21A and CYP11B1 was from 1 to 3 orders of magnitude less and that of CYP11B2 about 7 orders of magnitude less than in freshly dispersed cells (Fig. 8).

Baseline steroid-hormone secretion. HPLC assay showed that ZG cells cultured for 3 days on both plastic and Matrigel secreted sizeable amounts of post-pregnenolone steroid hormones, but the production was from 48 to $66 \%$ less than that of freshly-dispersed cells (Table II). As compared to plastic, Matrigel culture increased the cumulative production of ALDO, 18OH-CORT, CORT and PROG, did not affect $18 \mathrm{OH}-\mathrm{DOC}$ production, and lowered that of DOC (Fig. 9). The 180-min baseline production of all the steroid hormones assayed decreased with the duration of ZG-cell culture 

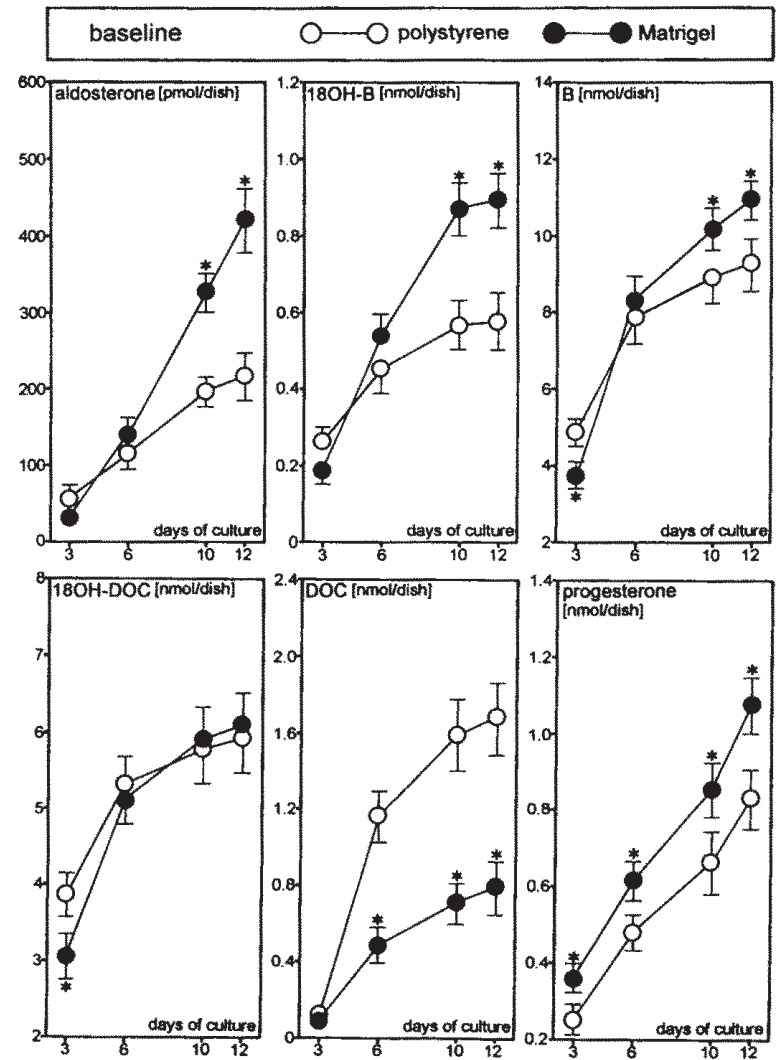

Figure 9. Baseline steroid-hormone cumulative secretion from rat ZG cells cultured on plastic (polystyrene) or Matrigel. Data are means \pm SEM $(n=4)$. ${ }^{*} \mathrm{P}<0.05$ from the respective plastic value.

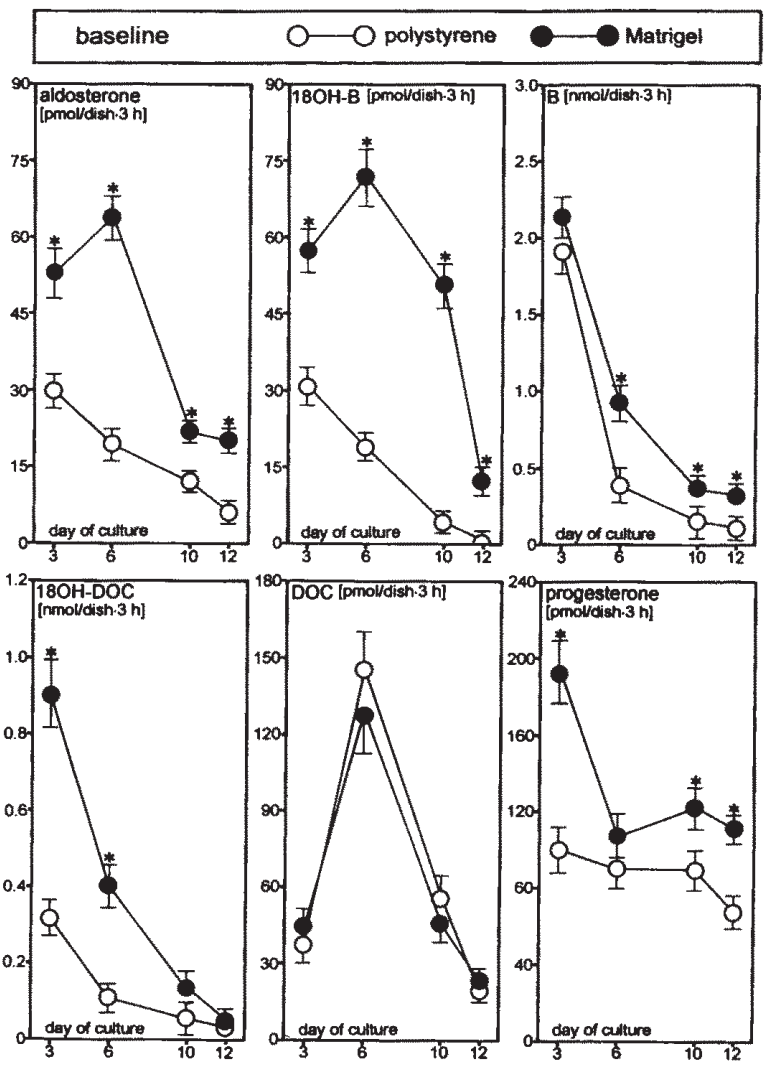

Figure 10. Baseline 180-min steroid-hormone production from rat ZG cells at days 3, 6, 10 and 12 of culture on plastic (polystyrene) or Matrigel. Data are means $\pm \operatorname{SEM}(\mathrm{n}=4) .{ }^{*} \mathrm{P}<0.05$ from the respective plastic value.
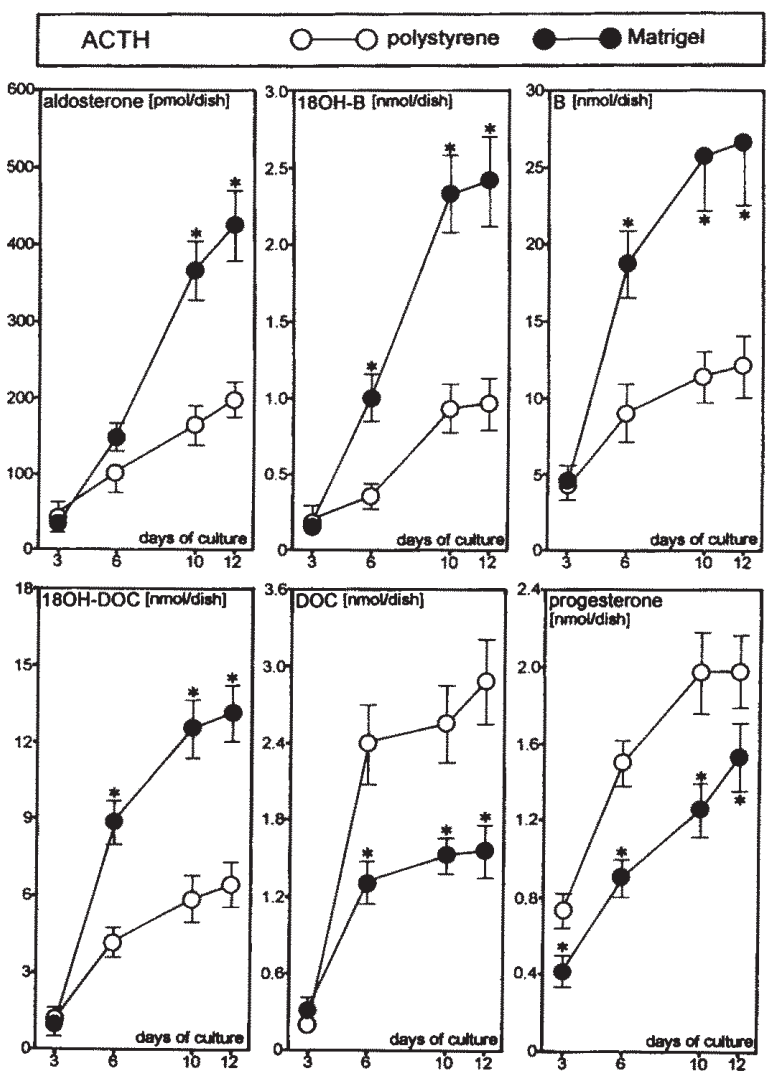

Figure 11. Effect of ACTH on steroid-hormone cumulative secretion from rat ZG cells cultured on plastic (polystyrene) or Matrigel. Data are means \pm SEM $(n=4) .{ }^{*} \mathrm{P}<0.05$ from the respective plastic value.
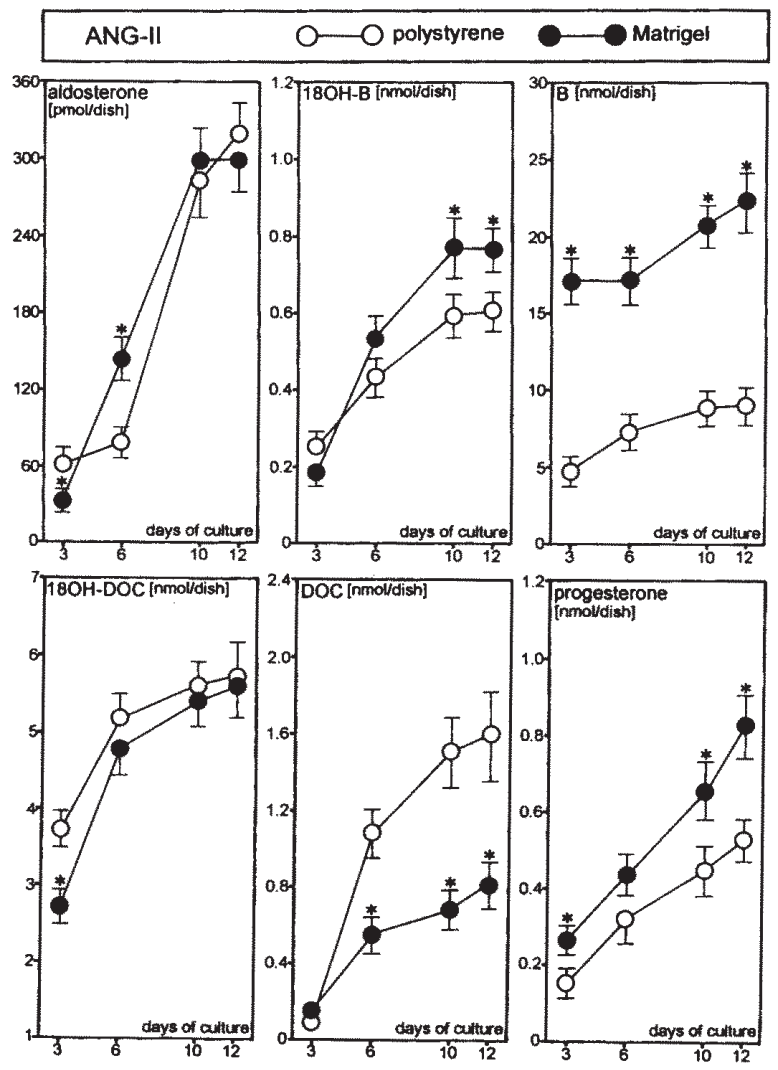

Figure 12. Effect of Ang-II on steroid-hormone cumulative secretion from rat ZG cells cultured on plastic (polystyrene) or Matrigel. Data are means \pm SEM $(n=4) .{ }^{*} \mathrm{P}<0.05$ from the respective plastic value. 

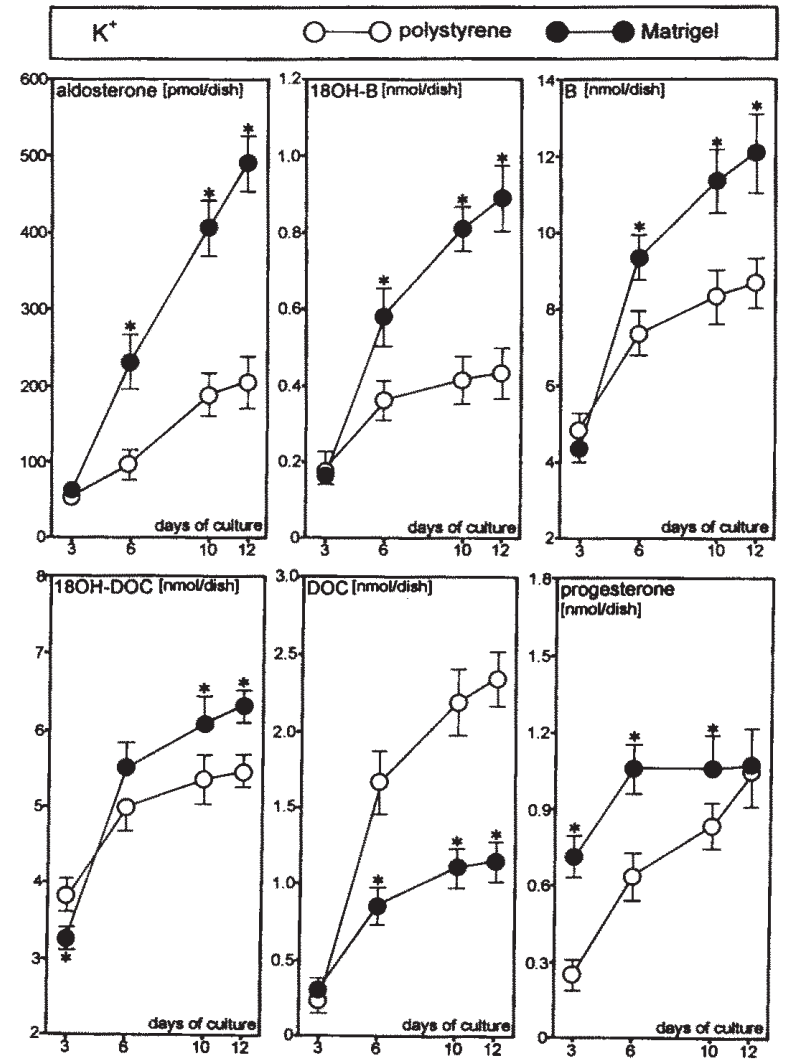

Figure 13. Effect of $\mathrm{K}^{+}$on steroid-hormone cumulative secretion from rat $\mathrm{ZG}$ cells cultured on plastic (polystyrene) or Matrigel. Data are means \pm SEM $(n=4) .{ }^{*} \mathrm{P}<0.05$ from the respective plastic value.
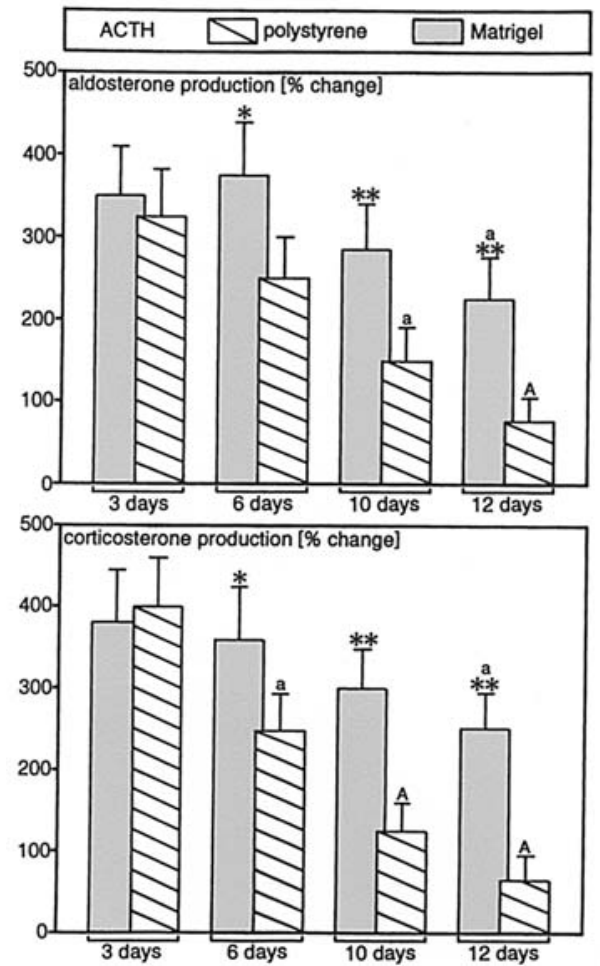

Figure 14. Aldosterone and corticosterone secretory response to ACTH of rat ZG cells at days 3, 6, 10 and 12 of culture on plastic (polystyrene) or Matrigel. Data are expressed as percent change from the respective baseline value. Bars are means $\pm \operatorname{SEM}(\mathrm{n}=4)$. ${ }^{*} \mathrm{P}<0.05$ and ${ }^{* *} \mathrm{P}<0.01$ from the respective plastic value; ${ }^{\mathrm{P}}<0.05$ and ${ }^{\mathrm{A}} \mathrm{P}<0.01$ from the respective 3 -day value.
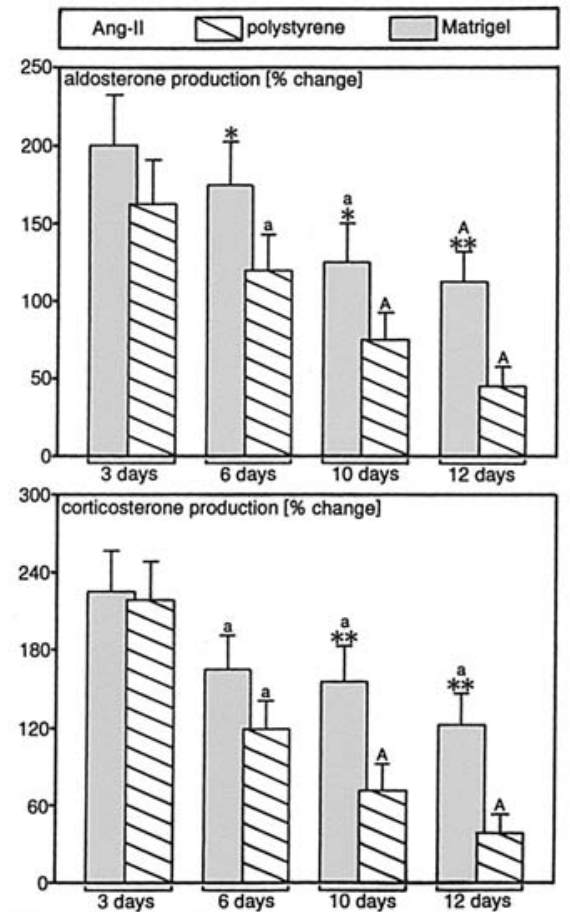

Figure 15. Aldosterone and corticosterone secretory response to Ang-II of rat ZG cells at days 3, 6, 10 and 12 of culture on plastic (polystyrene) or Matrigel. Data are expressed as percent change from the respective baseline value. Bars are means $\pm \operatorname{SEM}(\mathrm{n}=4) .{ }^{*} \mathrm{P}<0.05$ and ${ }^{* *} \mathrm{P}<0.01$ from the respective plastic value; ${ }^{\mathrm{a}} \mathrm{P}<0.05$ and ${ }^{\mathrm{A}} \mathrm{P}<0.01$ from the respective 3 -day value.

(Fig. 10). With the exception of DOC production, this parameter was significantly higher when cells were grown on Matrigel (Fig. 10). Noteworthy is that the 180-min production of ALDO and 18OH-CORT from ZG cells cultured on Matrigel was higher at day 6 than day 3 (Fig. 10).

Agonist-stimulated steroid-hormone secretion. As expected, the repeated exposure to agonists raised the cumulative secretion of post-pregnenolone steroid hormones. Matrigel favored the secretory response (Figs. 11-13), but striking differences were found depending on the agonist. Matrigel: i) enhanced $\mathrm{ACTH}$ - and $\mathrm{K}^{+}$-stimulated cumulative secretion of ALDO, 18OH-CORT, CORT and 18OH-DOC, but lowered that of DOC (Figs. 11 and 13), ii) augmented the Ang-IIstimulated cumulative production of $18 \mathrm{OH}-\mathrm{CORT}$ and CORT, leaving unchanged that of ALDO and $18 \mathrm{OH}-\mathrm{DOC}$ and decreasing that of DOC (Fig. 12); and iii) lowered ACTHstimulated PROG secretion (Fig. 11), but raised the Ang-IIand $\mathrm{K}^{+}$-stimulated one (Figs. 12 and 13). The acute response to agonists of the two main hormones secreted by rat $\mathrm{ZG}$ cells, i.e. ALDO and CORT (22), was assayed by measuring the 180-min hormone production before and after the exposure to agonists and calculating its percent change (Figs. 14-16). The secretory acute response to all agonists decreased with the number of days of culture on plastic. The response to ACTH and Ang-II of ZG cells also decreased with the duration of culture on Matrigel, although it was significantly higher than that of cells grown on plastic (Figs. 14 and 15). Conversely, the secretory response to $\mathrm{K}^{+}$did not undergo any change in relation to the number of days of culture on Matrigel (Fig. 16). 

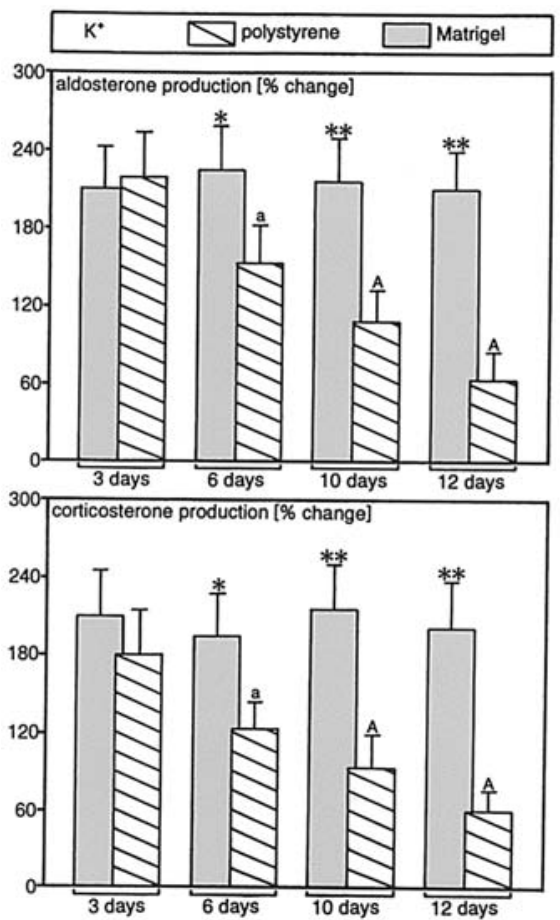

Figure 16. Aldosterone and corticosterone secretory response to $\mathrm{K}^{+}$of rat ZG cells at days 3, 6, 10 and 12 of culture on plastic (polystyrene) or Matrigel. Data are expressed as percent change from the respective baseline value. Bars are means $\pm \operatorname{SEM}(\mathrm{n}=4) .{ }^{*} \mathrm{P}<0.05$ and ${ }^{* *} \mathrm{P}<0.01$ from the respective plastic value; ${ }^{\mathrm{a}} \mathrm{P}<0.05$ and ${ }^{\mathrm{A}} \mathrm{P}<0.01$ from the respective 3 -day value.

\section{Discussion}

Definitive evidence indicates that steroid-hormone synthesis occurs via a complex pathway involving several enzymes located in both mitochondria and SER. The tubular arrangement of the mitochondria inner membrane, occurring in all steroidogenic cells, is thought to reflect the peculiar content of CYP enzymes (for review see refs. 1,22,23). Briefly, esterified cholesterol, stored in lipid droplets, is trasformed into free cholesterol, that reaches mitochondria, where StAR translocates it to the inner membrane. Here CYP11A transforms cholesterol to pregnenolone, which is released into the cytosol and sequentially converted to PROG and DOC by 3ßHSD and CYP21A located in SER. DOC enters again into mitochondria, where CYP11B1 11ß-hydroxylates it to CORT. ZG-cell mitochondria also possess CYP11B2, which catalyzes the conversion of DOC to ALDO, via three consecutive reactions: 11ß-hydroxylation of DOC to CORT, 18-hydroxylation of CORT to $18 \mathrm{OH}-\mathrm{CORT}$, and finally 18-methyloxidation of $18 \mathrm{OH}-\mathrm{CORT}$ to ALDO. CYP11B2 may also convert DOC to $18 \mathrm{OH}-\mathrm{DOC}$, which then is transformed into 18OH-CORT and ALDO (Fig. 1). ZG cells not only secrete CORT and ALDO, but also variable amounts of other postpregnenolone intermediate hormones (PROG, DOC, 18OHDOC, and 18OH-CORT), while under normal conditions pregnenolone is not released, because it is quantitatively converted to PROG. In fact, to assay the effect of agonists on the rate-limiting step of steroid synthesis (i.e. StAR/CYP11Amediated conversion of cholesterol to pregnenolone) is necessary to block 3ß-HSD activity.
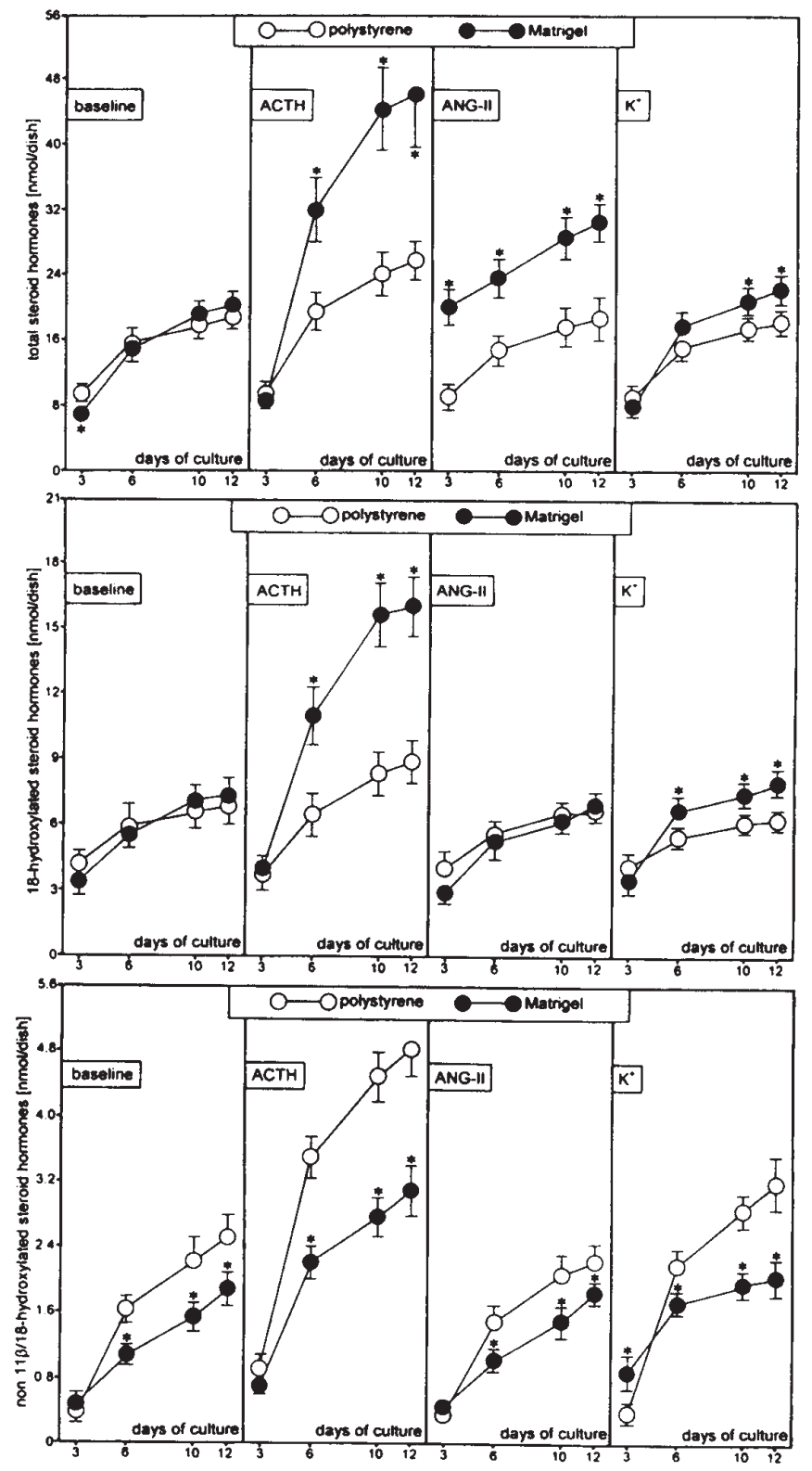

Figure 17. Baseline and agonist-stimulated cumulative secretion of total post-pregnenolone (upper panels), 11ß/18-hydroxylated (middle panels) and non-11ß/18-hydroxylated steroid hormones (lower panels) from rat ZG cells cultured on plastic (polystyrene) or Matrigel. Data are means $\pm \operatorname{SEM}(n=4)$. ${ }^{*} \mathrm{P}<0.05$ from the respective plastic value.

Our present findings clearly show that the culture on Matrigel allows rat ZG cells to retain their well differentiated phenotype for longer periods than the culture on plastic. ZG cells grown on plastic after 6 days display a fibroblast-like appearance and a net lowering in the expression of all steroidogenic enzymes, coupled to a decrease in both basal and agonist-stimulated steroidogenic capacity. In contrast, when cultured on Matrigel ZG cells exhibit the morphological features of actively steroid-secreting cells: mitochondria with tubular cristae, SER profiles and abundant lipid droplets. Moreover, the expression of the steroidogenic enzymes does not undergo appreciable changes and steroidhormone production, although decreasing in relation to the number of days of stay in culture, remains always higher than that of cells grown on plastic. 
The morphological feactures of ZG cells cultured on Matrigel requires further comments, especially as far as lipid droplets and mitochondria are concerned. Lipid droplets are abundant until day 12 of culture, raising the question of the source of esterified cholesterol stored in them. Cholesterol is prevalently taken-up from circulating high-density lipoproteins (HDL), through a receptor-mediated mechanism (scavenger receptor class B type I, SR-BI), or may be locally synthesized from acetate via a series of enzymes located in SER (24-26). Cultured ZG cells may obtain HDL from FCS added to the culture medium, and Matrigel could maintain either SR-BI expression or endogenous cholesterol SER synthesis. At days 10 and 12 of culture on Matrigel, ZG-cell mitochondria display laminar more than tubular cristae, but it is to be noted that this quite dedifferentiated morphology does not prevent mitochondria from participating in steroidogenesis in H-295 cells and adrenocortical-secreting tumors $(1,4)$.

Based on these lines of evidence, it is clear that the culture on Matrigel by preserving the expression of all steroidogenic enzymes favors the production of CORT and ALDO from ZG cells. Less clear is the effect of Matrigel on the production of other post-pregnenolone hormones, if the fact that our HPLC assay gives a dynamic picture of steroid synthesis is not taken into account. A decrease in the early intermediate products (PROG and DOC) may depend on either a lowering in the conversion of cholesterol to pregnenolone or to an enhanced utilization of them in CORT and ALDO synthesis. Hence, it is of interest to analyze the effects of Matrigel on baseline and agonist-stimulated total, 11ß-/18-hydroxylated, and non-11ß-/18-hydroxylated hormone production (Fig. 17). The analysis shows that Matrigel does not affect baseline total hormone cumulative production, but markedly raises the agonist-stimulated one: this depends on the apposite effects of Matrigel on 113-/18-hydroxylated and non-11ß-/18-hydroxylated hormone productions, which are either increased (ACTH- and $\mathrm{K}^{+}$-stimulated ones) or unaffected (baseline and Ang-II-stimulated ones) and decreased, respectively.

Our study also leads to other interesting conclusions: i) the conventional culture on plastic may be satisfactorily used in short-term experiments on rat ZG cells. The beneficial effect of Matrigel on the maintenance of ZG-cell differentiated phenotype becomes evident only starting from day 6 of culture; ii) 6 days of culture on Matrigel are needed for the full recovery of ZG-cell ALDO secretory capacity. The baseline 180-min production of both ALDO and $180 \mathrm{OH}-$ CORT is markedly higher at day 6 than at day 3 of growth on Matrigel; and iii) Matrigel culture favors the maintenance of the expression of either ACTH and Ang-II receptors or voltage-gated $\mathrm{Ca}^{2+}$ channels in $\mathrm{ZG}$ cells. The steroidogenic effects of ACTH and Ang-II are mediated by the MC2 $(27,28)$ and the AT1 receptors $(29)$, while $\mathrm{K}^{+}$depolarizes the cell plasma membrane with the ensuing opening of L-type $\mathrm{Ca}^{2+}$ channels $(30,31)$. Tissue culture on plastic causes a time-dependent decrease in the secretory response of ZG cells to all their main agonists, while the growth on Matrigel maintains higher the response to ACTH and Ang-II and unchanged that to $\mathrm{K}^{+}$.

Only speculations are at present possible on the mechanisms underlying Matrigel effects on cultured rat ZG cells. However, evidence has accumulated that extracellular matrix plays an important role in the functional control of adrenocortical cells. Adrenocortical cells are able to produce matrix components (laminin, fibronectin, collagen I and collagen IV) and possess integrin receptors (32-36). Extracellular matrix was found to contribute to the maintenance of 11ß-hydroxylase and c21hydroxylase activity in cultured bovine adrenocortical cells (37), and collagen IV and fibronectin to enhance 3ß-HSD and CYP17 (17 $\alpha$-hydroxylase) mRNA expression and to maintain the nuclear localization of DAX-1 in cultured human fetal adrenocortical cells $(38,39)$. Finally, the various extracellular matrix components have been shown to variously affect either basal or agonist-stimulated steroid production from cultured adrenocortical cells: collagen IV enhances ACTHand Ang-II-stimulated cortisol and dehydroepiandrosterone (DHEA) secretion; fibronectin and laminin decrease ACTHstimulated cortisol, but raise DHEA production, and finally fibronectin, by interacting with integrin receptors, favors ACTH- and Ang-II-stimulated ALDO secretion from rat ZG cells grown on poly-1-lysine coverslips $(36,38,40)$. In this connection, we recall that extracellular matrix has been reported to enhance steroid-hormone production from porcine and ovine ovary granulosa cells $(41,42)$, and to control ACTH secretion from pituitary corticotrophs $(43,44)$. The major components of Matrigel are laminin, collagen IV and heparan sulfate proteoglycans (8), and in light of the above reviewed investigations it appears likely that, by interacting with integrin receptors, Matrigel may favor the long-term maintenance of the differentiated phenotype of rat ZG cells in culture. In view of the specific effect of fibronectin on ALDO secretory capacity of rat ZG cells $(36,40)$, further investigations are under way to examine whether the addiction of fibronectin to Matrigel could improve our culture technique.

\section{Acknowledgments}

We thank Ms. A. Coi for help in the search and delivery of bibliographic items.

\section{References}

1. Nussdorfer GG: Cytophysiology of the adrenal cortex. Int Rev Cytol 98: 1-405, 1986.

2. Rainey WE, Saner K and Schimmer BR: Adrenocortical cell lines. Mol Cell Endocrinol 228: 23-38, 2004.

3. Albertin G, Carraro G, Petrelli L, Guidolin D, Neri G and Nussdorfer GG: Endothelin-1 and adrenomedullin enhance the growth of human adrenocortical carcinoma-derived SW-13 cell line by stimulating proliferation and inhibiting apoptosis. Int $\mathbf{J}$ Mol Med 15: 469-474, 2005.

4. Andreis PG, Rucinski M, Neri G, Conconi MT, Petrelli L, Parnigotto PP, Malendowicz LK and Nussdorfer GG: Neuropeptides $\mathrm{B}$ and $\mathrm{W}$ enhance the growth of human adrenocortical carcinoma-derived NCI-H295 cells by exerting MAPK p42/p44mediated proliferogenic and antiapoptotic effects. Int J Mol Med 16: 1021-1028, 2005.

5. Mukai K, Nagasawa H, Agake-Suzuki R, Mitani F, Totani K, Yanai N, Obinata M, Suematsu M and Ishimura Y: Conditionally immortalized adrenocortical cell lines at undifferentiated states exhibit inducible expression of glucocorticoid-synthesizing genes. Eur J Biochem 269: 69-81, 2002.

6. Lukashev $\mathrm{M}$ and Werb Z: ECM signaling: orchestrating cell behavior and misbehavior. Trends Cell Biol 8: 437-441, 1998.

7. Chamoux E, Otis M and Gallo-Payet N: A connection between extracellular matrix and hormonal signals during the development of the human fetal adrenal gland. Braz J Med Biol Res 38: 1495-1503, 2005. 
8. Kleinman HK, McGarvey ML, Liotta LA, Gehron-Robey P, Tryssvason K and Martin GR: Isolation and characterization of type IV procollagen, laminin, and heparan sulfate proteoglycan from the EMS sarcoma. Biochemistry 21: 6188-6193, 1982 .

9. Hadley MA, Byers SW, Suarez-Quian CA, Kleinman HK and Dym M: Extracellular matrix regulates Sertoli cell differentiation, testicular cord formation, and germ cell development in vitro. J Cell Biol 101: 1511-1522, 1985.

10. Kleinman HK, McGarvey ML, Hassel JR, Star VL, Cannon FB, Laurie GW and Martin GR: Basement membrane complexes with biological activity. Biochemistry 25: 312-318, 1986.

11. McGuire PG and Orkin RW: Isolation of rat aortic endothelial cells by primary explant techniques and their phenotypic modulation by defined substrata. Lab Invest 57: 94-105, 1987.

12. Kubota Y, Kleinman HK, Martin GR and Lawley TJ: Role of laminin and basement membrane in the morphological differentiation of human endothelial cells into capillary-like structures. J Cell Biol 107: 1589-1598, 1988

13. Malendowicz LK, Spinazzi R, Tortorella C, Nussdorfer GG, Ziolkowska A and Rucinski M: Effects of leptin and leptin fragments on corticosterone secretion and growth of cultured rat adrenocortical cells. Int J Mol Med 14: 873-878, 2004.

14. Mazzocchi G, Rossi GP, Neri G, Malendowicz LK, Albertin G and Nussdorfer GG: 11ß-hydroxysteroid dehydrogenase expression and activity in the human adrenal cortex. FASEB J 12: 1533-1539, 1998.

15. Ziolkowska A, Rucinski M, Neri G, Di Liddo R, Nussdorfer GG and Malendowicz LK: Expression of the beacon gene in the rat adrenal gland: direct inhibitory effect of beacon[47-73] on aldosterone secretion from dispersed adrenal zona glomerulosa cells. Int J Mol Med 13: 215-219, 2004.

16. Albertin G, Rucinski M, Carraro G, Forneris M, Andreis PG, Malendowicz LK and Nussdorfer GG: Adrenomedullin and vascular endothelium growth factor genes are overexpressed in regenerating rat adrenal cortex, and AM and VEGF reciprocally enhance their mRNA expression in cultured rat adrenocortical cells. Int J Mol Med 16: 431-435, 2005.

17. Albertin G, Carraro G and Nussdorfer GG: Human adrenomedullin gene silencing by short interfering RNAs: a preliminary study. Int J Mol Med 15: 579-583, 2005.

18. Rucinski M, Andreis PG, Ziolkowska A, Nussdorfer GG and Malendowicz LK: Differential expression and function of beacon in the rat adrenal cortex and medulla. Int J Mol Med 16: 35-40, 2005.

19. Pfaffl MW: A new mathematical model for relative quantification in real-time RT-PCR. Nucleic Acids Res 29: 2002-2007, 2001.

20. Neri G, Malendowicz LK, Andreis PG and Nussdorfer GG: Thyrotropin-releasing hormone inhibits glucocorticoid secretion of rat adrenal cortex: in vivo and in vitro studies. Endocrinology 133: 511-514, 1993.

21. Hochol A, Albertin G, Nussdorfer GG, Spinazzi R, Ziolkowska A, Rucinski M and Malendowicz LK: Effects of neuropeptides B and $\mathrm{W}$ on the secretion and growth of rat adrenocortical cells. Int J Mol Med 14: 843-847, 2004.

22. Vinson GP and Hinson JP: Blood flow and hormone secretion in the adrenal gland. In: The Adrenal Gland. James VTH (ed). Raven Press, New York, pp71-86, 1992.

23. Connell JMC and Davies E: The new biology of aldosterone. J Endocrinol 186: 1-20, 2005.

24. Capponi AM: Regulation of cholesterol supply for mineralocorticoid biosynthesis. Trends Endocrinol Metab 13: 118-121, 2002.

25. Connely MA and Williams DL: SR-BI and cholesterol uptake into steroidogenic cells. Trends Endocrinol Metab 14: 467-472, 2003.

26. Black VH, Sanjay A, van Leyen K, Lauring B and Kreibich G: Cholesterol and steroid synthesizing smooth endoplasmic reticulum of adrenocortical cells contains high levels of proteins associated with the traslocation channel. Endocrinology 146: 4234-4249, 2005.
27. Mountjoy KG, Robbins LS, Mortrud MT and Cone RD: The cloning of a family of genes that encode the melanocortin receptors. Science 257: 1248-1251, 1992.

28. Elias LLK and Clark AJL: The expression of the ACTH receptor. Braz J Med Biol Res 33: 1245-1248, 2000.

29. De Gasparo M, Catt KJ, Inagami T, Wright JW and Unger TH: International union of pharmacology. XXIII. The angiotensin II receptors. Pharmacol Rev 52: 415-472, 2000.

30. Spät A and Hunyady L: Control of aldosterone secretion: a model for convergence in cellular signaling pathways. Physiol Rev 84: 489-539, 2004.

31. Uebele VN, Nuss CE, Renger JJ and Connolly TM: Role of voltage-gated calcium channels in potassium-stimulated aldosterone secretion from rat adrenal zona glomerulosa cells. J Steroid Biochem Mol Biol 92: 209-218, 2004

32. Pellerin S, Keramidas M, Chambaz E and Feige J: Expression of laminin and its possible role in adrenal cortex homeostasis. Endocrinology 138: 1321-1327, 1997.

33. Feige J, Keramidas M and Chambaz E: Hormonally regulated components of the adrenocortical cell environment and the control of adrenal cortex homeostasis. Horm Metab Res 30: 421-425, 1998.

34. Chamoux E, Bolduc L, Lehoux JG and Gallo-Payet N: Identification of extracellular matrix components and their integrin receptors in the human fetal adrenal gland. J Clin Endocrinol Metab 86: 2090-2098, 2001.

35. Virtanen I, Korhonen M, Petäjäniemi N, Karhunen T, Thornell LE, Sorokin LM and Kontlinen YT: Laminin isoforms in fetal and adult human adrenal cortex. J Clin Endocrinol Metab 88: 4960-4966, 2003.

36. Campbell S, Otis M, Côté M, Gallo-Payet N and Payet MD: Connection between integrins and cell activation in rat adrenal glomerulosa cells: a role for Arg-Gly-Asp peptide in the activation of the $\mathrm{p} 42 / \mathrm{p} 44^{\mathrm{mapk}}$ pathway and intracellular calcium. Endocrinology 144: 1486-1495, 2003.

37. Cheng $\mathrm{C}$ and Hornsby P: Expression of $11 B$-hydroxylase and 21-hydroxylase in long-term cultures of bovine adrenocortical cells requires extracellular matrix factors. Endocrinology 130: 2883-2889, 1992.

38. Chamoux E, Narcy A, Lehoux JG and Gallo-Payet N: Fibronectin, laminin and collagen IV as modulators of the cell behavior during adrenal gland development in the human fetus. J Clin Endocrinol Metab 87: 1819-1828, 2002.

39. Battista MC, Otis M, Côté M, Laforest A, Peter M, Lalli E and Gallo-Payet N: Extracellular matrix and hormones modulate DAX-1 localization in the human fetal adrenal gland. J Clin Endocrinol Metab 90: 5426-5431, 2005.

40. Campbell S, Otis M, Gallo-Payet N and Payet MD: Role of extracellular matrix components in adult rat adrenal gland homeostasis. Endocr Res 30: 609-610, 2004.

41. Sites CK, Kessel B and La Barbera AR: Adhesion proteins increase cellular attachment, follicle-stimulating hormone receptors, and progesterone production in cultured porcine granulosa cells. Proc Soc Exp Biol Med 212: 78-83, 1996.

42. Huet C, Pisselet C, Mandon-Pépin B, Monget P and Monniaux D: Extracellular matrix regulates ovine granulosa cell survival, proliferation and steroidogenesis: relationships between cell shape and function. J Endocrinol 169: 347-360, 2001.

43. Kuchenbauer F, Hopfner U, Stalla J, Arzt E, Stalla GK and Paez-Pereda M: Extracellular matrix components regulate ACTH production and proliferation in corticotroph tumor cells. Mol Cell Endocrinol 175: 141-148, 2001.

44. Paez-Pereda M, Kuchenbauer F, Arzt E and Stalla GK: Regulation of pituitary hormones and cell proliferation by components of the extracellular matrix. Braz J Med Biol Res 38: 1487-1494, 2005. 